\title{
Prevalence of Ticks on Camels and Cattle Brought to Dodoru Market Kebbi State, Nigeria
}

\author{
Yahaya Muhammad Abdullahi ${ }^{1}$, Ibrahim Muhammad Magami ${ }^{1}$, Ahmed Audu ${ }^{1}$, \\ Muhammad Murtala Mainasara ${ }^{2}$ \\ ${ }^{1}$ Usmanu Danfodiyo University, Sokoto \\ P. M. B. 2346, Sokoto, Nigeria \\ ${ }^{2}$ Universiti Tun Hussein Onn Malaysia \\ 101 Parit Raja, Batu Pahat, Johor, 86400, Malaysia
}

DOI: $10.22178 /$ pos.33-4

LCC Subject Category: QH540-549.5

Received 06.02.2018

Accepted 01.03.2018

Published online 12.04.2018

Corresponding Author:

Yahaya Muhammad Abdullahi

yahayamaduna@gmail.com

(c) 2018 The Authors. This article is

licensed under a Creative Commons

Attribution 4.0 License
Abstract. Dodoru Market is popular for its weekly Market day in Kebbi State, Nigeria. People converge at the market every Monday from various places to buy or sell. Survey of ticks on camels and cattle brought to Dodoru Market for sale was conducted. The aim was to evaluate the prevalence of camel and cattle ticks. A total of 90 animals (40 camels and 50 cattle) were examined. Five tick species were identified and prevalence was evaluated. Results revealed that 32 of the camels were infected with the prevalence of $35.6 \%$ and cattle were also infested with $44.4 \%$ prevalence. Boophilus decoloratus has the highest prevalence of $29.1 \%$ in both camels and cattle. Thigh and abdomen were more susceptible to ticks species with the prevalence of $37.7 \%$. The survey also shows that cattle were more infested than camels and thigh/abdomen was observed to be the most preferred locations for ticks in both camels and cattle.

Keywords: camels; cattle; Dodoru; survey; ticks.

\section{INTRODUCTION}

The most major limiting factors for maintaining more profits from the livestock industry is the effects of ticks or tick-borne diseases [4]. Prevalence of ectoparasites and their infestation on various parts of domesticated animals are issues of high importance in veterinary science [5]. Ticks (Arachnida: Acari: Parasitiformes) are hematophagous ectoparasitic arthropods which are considered significant, acting as vectors of pathogens which include; Anaplasma, Babesia, Thileria, Rickettsia and Borrelia Species. When found on the host, they suck blood thereby inducing anaemia, skin irritation etc to the host. They are also responsible for a serious economic loss in animal farms, livestock, due diseases they caused $[2,13,10]$.

Camels are not common among the livestock domesticated animals in Sokoto, Kebbi and Zamfara States, though highly adapted to semi-arid, their survival in arid and semi-arid regions is common due to their physiological, morphologically and behavioural adaptation to heat, lack of water and availability of fodder [14]. This made researchers conclude that there is great scope for improving husbandry method and selective breeding to increase their productivity. It was also suggested that to exploit Camels potentials, there is need to improve its health status as other domesticated animals such as sheep. Cattle are domesticated animals which belong to family Bovidae, In Nigeria Cattle has to mean population of 13.9 Million in which 11.5 Million of this were kept under pastoral in 1990 [8]. Camels, as well as Cattle, are suffering from a number of diseases as other livestock [13], and one of the contributing factors are parasites infestation. These parasites and their capacity for disease transmission are important economic limiting factors to production in animal farms [9]. Kebbi State has considerable water resources which serve as an 
ideal area for agriculture and animal rearing, but there is not enough information concerning tick checklist of Cattle and Camels. Therefore, the present study was conducted on this background to survey the infestation and prevalence of Camel and Cattle ticks brought to Dodoru Market, Kebbi State, Nigeria.

\section{MATERIALS AND METHODS}

Study Area. Dodoru Market is under Gwandu Local Government area of Kebbi State, it's located in Northwestern Nigeria within longitude $4^{\circ} 39^{\prime}$ $48^{\prime \prime} \mathrm{N}$ and latitude $12^{\circ} 24^{\prime} 05^{\prime \prime} \mathrm{E}$. The area experienced two seasons (wet and dry), wet season last from May to September, while dry season last from October to April. The mean annual rainfall is $800 \mathrm{~mm}$. Temperature is high with annual mean of $26{ }^{\circ} \mathrm{C}$. However during a dry season, specifically (December to February) the temperature can be low as $21{ }^{\circ} \mathrm{C}$ and up $43{ }^{\circ} \mathrm{C}$ at the peak of a dry season (April to June). Dodoru weekly market day can be notice from its booming activities since from Thursdays, as traders begin to move their commodities from various destinations for the Market day [11].

Sample Collection. Samples were collected from Dodoru livestock Market between May to June 2014, during which 40 Camels and 50 Cattle were randomly examined. Both physical examination and laboratory investigation were employed. Ticks samples collected were preserved in sample bottles containing $70 \%$ of alcohol prior identification.

Sample Identification. Identification of ticks collected from different parts of infestation was carried out in Entomology Laboratory, Usmanu Dan- fodiyo University, Sokoto. Scientists [12] identification guide of tick species was used.

Statistic Analyse. Data obtained were recorded; prevalence between Camels and Cattle, ticks infestation was also evaluated. Their percentages of prevalence were also tabulated. While $5 \%$ was considered as the level of significance.

\section{RESULTS AND DISCUSSION}

Total of 90 animals were examined out of which 40 were Camels and 50 Cattle (Table 1 ).

Table 1 - Number of Camels, Cattle Examined, Infested and Prevalence of Ticks

\begin{tabular}{|l|c|c|c|}
\hline \multicolumn{1}{|c|}{ Characteristics } & Camels & Cattle & Total \\
\hline Number Examined & 40 & 50 & 90 \\
\hline Number Infested & 32 & 40 & 72 \\
\hline & $80.0 /$ & $80.0 /$ & 80.0 \\
Prevalence (\%) & 35.6 & 44.4 & \\
\hline
\end{tabular}

Seventy-two out of 90 inspected animals were infested with ticks, the mean number of ticks on each animal was (6-10 ticks per animal), the occurrence of ticks on cattle and camels were $80.0 \%$.

The predominance of Boophilus species over Hyalomma and Amblyomma species on camels and cattle was observed, therefore agreeing with the findings of [3]. Among 600 ticks species identified Boophilus decoloratus was found to be predominant with prevalence (Table 2) of 175 (29.1\%) followed by Boophilus annulatus with 135 (22.5\%), Hyalomma truncatum with 120 species $(20 \%)$.

Table 2 - Prevalence of Ticks Species on Camels and Cattle at Dodoru Market, 2015

\begin{tabular}{|l|c|c|c|c|}
\hline \multicolumn{1}{|c|}{ Species } & Camels & Cattle & Total & Prevalence (\%) \\
\hline Boophilus decoloratus & 59 & 116 & 175 & 29.1 \\
\hline Boophilus annulatus & 55 & 80 & 135 & 22.5 \\
\hline Hyalomma truncatum & 63 & 57 & 120 & 20.0 \\
\hline Amblyomma variegatum & 32 & 59 & 91 & 15.2 \\
\hline Hyalomma dromedarii & 79 & Not present & 79 & 13.2 \\
\hline
\end{tabular}

A. variegatum has 91 species (15.2\%) and the least was Hyalomma dromedarii with 79 species (13.2\%), though predominance of Boophilus decoloratus was in accordance with the findings of $[1,5]$.
Infestation of ticks according to body parts on cattle and camels (Table 3) shows that prevalence of $37.7,22.0,20.2,13.1$ and $7 \%$ were recorded for thigh and abdomen, dorsal surface, neck and dewlap, ear region and tail/anal region respectively for both cattle and camels. 
Table 3 - Prevalence of Ticks Base on Location on Camels and Cattle Body Parts

\begin{tabular}{|l|c|c|c|c|}
\hline Location & Camel & Cattle & Total & $\begin{array}{c}\text { Prevalence } \\
(\%)\end{array}$ \\
\hline $\begin{array}{l}\text { Thigh and } \\
\text { Abdomen }\end{array}$ & 106 & 120 & 226 & 37.7 \\
\hline $\begin{array}{l}\text { Dorsal Sur- } \\
\text { face }\end{array}$ & 53 & 79 & 132 & 22.0 \\
\hline $\begin{array}{l}\text { Neck and } \\
\text { Dewlap }\end{array}$ & 55 & 66 & 121 & 20.2 \\
\hline Ear Region & 32 & 47 & 79 & 13.1 \\
\hline $\begin{array}{l}\text { Tail/anal } \\
\text { Region }\end{array}$ & 24 & 18 & 42 & 7.0 \\
\hline Total & 270 & 330 & 600 & 100 \\
\hline
\end{tabular}

Hyalomma dromedarii was identified only on Camels. This may be due to temperature variation, ease of penetrating by the hypostome, accessibility of blood vessels in different parts of the body [8], also supported by [5] who reported that the species were introduced on cattle and goats by [10]. Authors [7], findings were closely related to the present study, whom reported that A. variagatum has $22.5 \%$ as the common species identified, followed by B. decoloratus - $17.5 \%$, Hyalomma - $6.7 \%$ and R. sanquineus - $3.3 \%$. The present study also shows that male ticks were more prevalence than females on both cattle and camels where males on cattle were $30.2 \%$, on camels $-27.2 \%$ and females on cattle were $2.8 \%$ and on camels - $20.8 \%$ therefore, contrary to [5] findings, where females ticks dominated. Relative number between male and female ticks is possibly due females being more likely to be removed by host groomed because engorged females can detached from their host, while males can remain on the host for a long time, which results to preponderance of male than female ticks [6].

The result of Chi-Square test on the relationship between tick species of camels and cattle shows that some species of ticks are more associated with camels than cattle (Table 4).

Table 4 - Chi-Square test for relationship between Ticks Species on Camels and Cattle

\begin{tabular}{|l|c|c|c|}
\hline & Value & df & $\begin{array}{l}\text { Asymp. Sig. } \\
\text { (2-sided) }\end{array}$ \\
\hline Pearson Chi-Square & 109.722 & 4 & .000 \\
\hline Likelihood Ratio & 140.555 & 4 & .000 \\
\hline N of Valid Cases & 600 & & \\
\hline
\end{tabular}

While on the relationship between ticks base on locations on camels and cattle body parts it was observed that there was an association between ticks according to locations vs their body parts. This implies that ticks attack body parts of camels and cattle evenly (Table 5).

Table 5 - Chi-Square test for relationship between Ticks Base on Location on Camels and Cattle Body Parts

\begin{tabular}{|l|c|c|c|}
\hline & Value & df & $\begin{array}{l}\text { Asymp. Sig. } \\
\text { (2-sided) }\end{array}$ \\
\hline Pearson Chi-Square & 4.741 & 4 & .315 \\
\hline Likelihood Ratio & 4.740 & 4 & .315 \\
\hline N of Valid Cases & 600 & & \\
\hline
\end{tabular}

\section{CONCLUSION}

The survey reveals that five species of ticks were common to camels and cattle, which may have health effects on them. The spread of these ectoparasites may occur due to movements from different areas. Soft body parts were found to be more susceptible to ticks infestation. Therefore the following recommendations were drawn; screening and treatment of animals brought to the market, animals infested should be fenced and the government should encourage nomadic education, especially in rural areas and more studies on these ticks should be carried out.

\section{REFERENCES}

1. Abebe, R., Fantahun, T., Abera, M., \& Bekele, J. (2010). Survey of ticks (Acari: Ixodidae) infesting cattle in two districts of Somali Regional State, Ethiopia. Veterinary World, 3(12), 539-543.

2. Branscheid, W., \& Schroer, C. (1997). Damage to cattle hides, detection, frequency and economic importance. Fleischwirtschaft, 77, 333-337.

3. James-Rugu, N., \& Jidayi, S. (2004). A survey on the ectoparasites of some livestock from some areas of Borno and Yobe States. Nigerian Veterinary Journal, 25(2), 48-55. doi:

10.4314/nvj.v25i2.3474 
4. Kocan, K. M. (1995). Targeting ticks for control of selected hemoparasitic diseases of cattle. Veterinary Parasitology, 57(1-3), 121-151. doi: 10.1016/0304-4017(94)03116-E

5. Moghaddam, A. G., Seyed, M. R., Rasouli, M., Hosseinzade, S., Darvishi, M. M., Rakhshanpour, A., \& Rahimi, M. T. (2014). Survey on cattle ticks in Nur, north of Iran. Asian Pacific Journal of Tropical Biomedicine, 4(3), 209-212. doi: 10.1016/S2221-1691(14)60233-1

6. Mohammed, M. S., \& Hassan, S. M. (2007). Distribution and population dynamics of ticks (Acari: Ixodidae) infesting sheep in Sennar State, Sudan. Onderstepoort J Vet Res, 74(4), 301-306. doi: 10.1016/j.vetpar.2012.03.032

7. Obadiah, H., \& Shekaro, A. (2012). Survey of Tick Infestation in Cattle in Zaria Abattoir, Nigeria. Journal of Veterinary Advances, 2(2), 81-87.

8. Opara, M. N., Nwaobasi, J. K., \& Okoli, I. C. (2005). Occurrence of parasitic helminths among small ruminants reared under traditional husbandry system in Owerri, South East Nigeria. Bulletin of Animal Health Production Africa 53(4), 226-233. doi: 10.4314/bahpa.v53i4.32715

9. Pegram, G., \& Higgins, S. (1992). Camel Ectoparasites. Proceedings of 1st international Camel Conference, 69-78.

10. Shemshad, K., Rafinejad, J., Kamali, K., Piazak, N., Sedaghat, M. M., Shemshad, M., ... Enayati, A. A. (2011). Species diversity and geographic distribution of hard ticks (Acari: Ixodoidea: Ixodidae) infesting domestic ruminants, in Qazvin Province, Iran. Parasitology Research, 110(1), 373-380. doi: $10.1007 / \mathrm{s} 00436-011-2501-6$

11. USAID. (2008). Nigeria Food Security Outlook. Famine Early Warning Systems Network, OctoberDecember 2008. Retrieved April 9, 2018, from

https://reliefweb.int/sites/reliefweb.int/files/resources/495BC9951EF7C9C0492574DC0004E 99A-Full_Report.pdf

12. Walker, A. R., Bouattour, A., Camicas, J. L., Estrada-Pena, A., Horak, I. G., Latif, A. A., Pegram R. G. \& Preston, P. M. (2003). Ticks of Domestic Animals in Africa: a Guide to Identification of Species. Edinburgh: The University of Edinburgh.

13. Wall, R., \& Shearer, D. (Eds.). (2001). Veterinary Ectoparasites: Biology, Pathology and Control. doi: 10.1002/9780470690505

14. Yagil, R. (1988). Endocrine involvement in adaptation to heat and desiccation. Experimental.Clinical Endocrinology. 7, 131-137. 